\title{
NO MAN'S LAND
}

\section{José Tomás Pérez}

\author{
Escuela de Arquitectura, Pontificia Universidad Católica de Chile \\ Santiago, Chile \\ Triángulo terrestre, \\ Chile/Perú \\ ○
}

Given the longstanding border disputes between Chile and Peru - enhanced by the 2014 International Court of Justice verdict that left a triangular area in a strange legal ambiguity - this project imagines an architectural solution to a geopolitical conflict: subtracting the disputed territory in order to duplicate the coastline for both countries. Thus, the only possible confrontation would be that of two beaches overlooking one country from another.

KEYWORDS - border, beach, subtraction, conflict, geopolitics

This research was part of the Architecture degree project presented in April 2016. The place corresponds to the interregnum known as terrestrial triangle, ${ }^{1}$ the space that represents the border dispute between Chile and Peru.

The operation was based on the place's subtraction- by removing the volume of land and its captive ocean inlet followed by the addition of a road section between the ports of Arica and Ilo.

The project's starting point was the difficulty in finding solutions to border conflicts in South America during recent decades, triggering international trials involving large amounts of time and money, ${ }^{2}$ increasing distrust and blocking the territories for indefinite periods. In contrast, subtraction explores a potential strategic subversion: defusing the conflict through physical transformation of

I The controversy behind the project is that of the terrestrial triangle: 37,000 $\mathrm{m}^{2}$ of disputed land between the Milestone $\mathrm{N}^{\circ} \mathrm{I}$ and the low tide line. The case derives from the trial before the International Court of Justice of Peru and Chile's maritime dispute and its verdict in 2014.

2 Between 2008 and 20I4, the State of Chile spent Us $\$$ I6.5 million in connection with the defense before the International Court of Justice on the maritime dispute (La Tercera, 2014). 


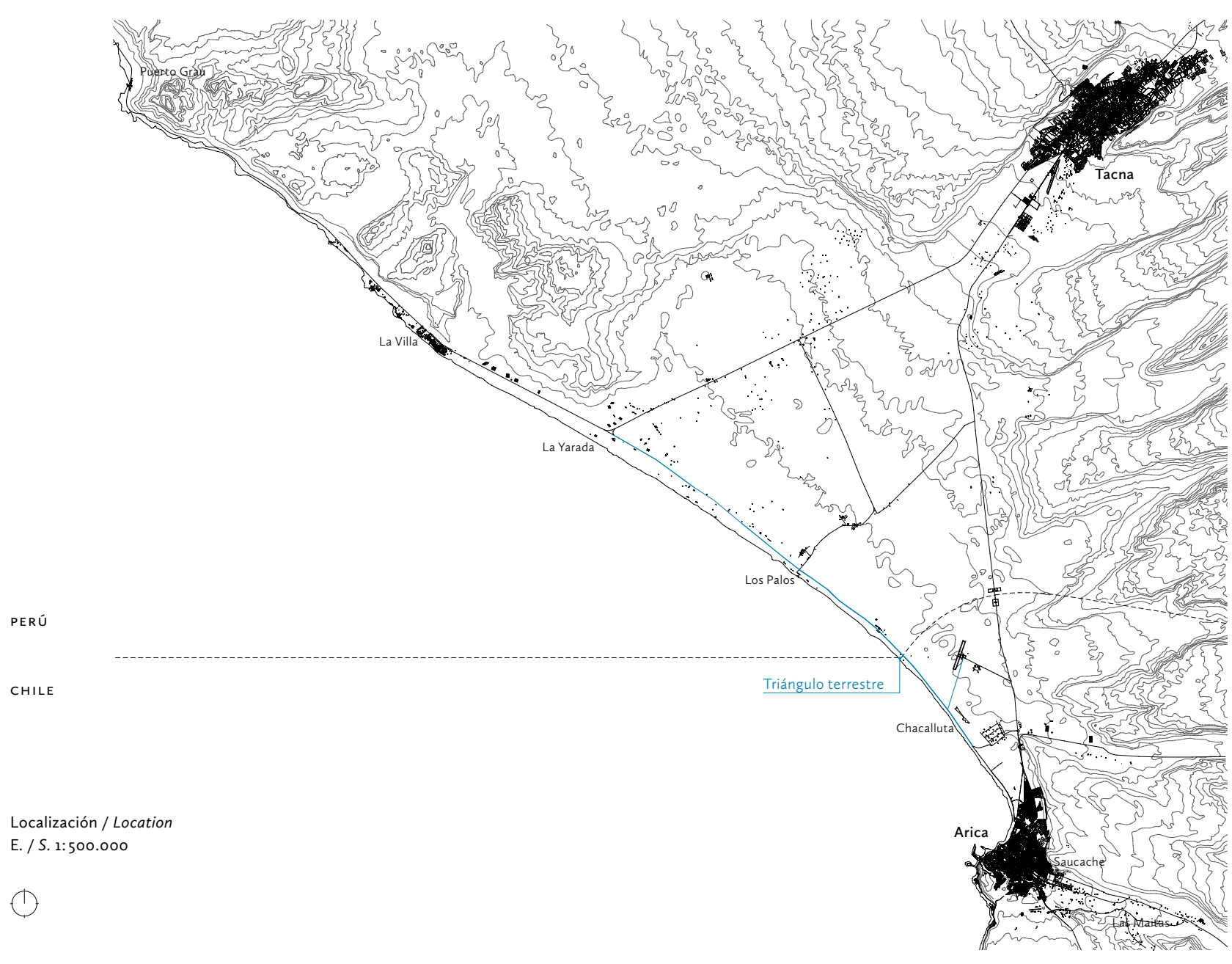

the territory. In other words, a formal exit for the politicized interregnum. $^{3}$

In political terms, the land's subtraction supports a position: the recognition of the juxtaposition of sovereignties. It admits on the one hand the dry shore claimed by Peru and, on the other, the Pacific Ocean entrance under Chilean control, forming as a result a system of embankments surrounding an artifact of uncertain sovereignty: a territorial-scale water pool. As opposed to a monument, the project investigates the possibility of oblivion from the viewpoint of the ruin's appealing imaginary, that is, between the disappearance and the remains of the original controversy.

Regionally, the subtractive drive exorcises the impossibility of a relationship between countries, while opposing the dividing logic existing within the 30-kilometers beach adjacent to the border. Thus, revisiting the plan for connecting both sides allows

3 An example is the proposal by the architects Humberto Eliash, Fernando Castillo Velasco and Carlos Martner, positioning on the Bolivian sea access affair. The project is based on a tunnel and an artificial island - paradoxically, engineering works. The key, however, was to abandon the traditional notion of the border as a line, considering instead its height. Understanding land as a volume was a characteristic shared with this project. In order to research on this proposal, I interviewed Humberto Eliash. 

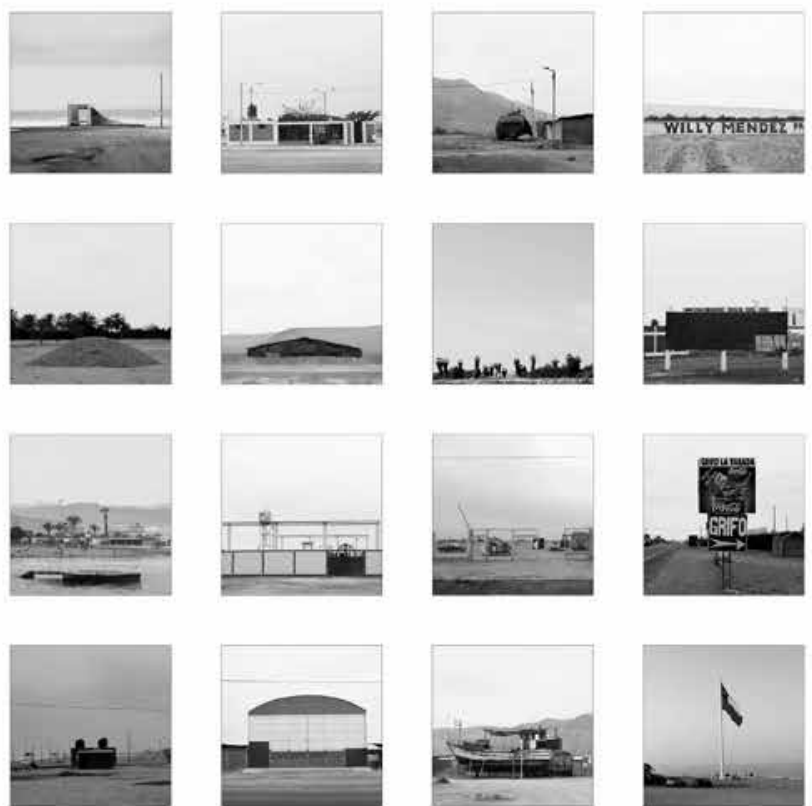

Levantamiento fotográfico Tacna - Arica. Septiembre 2015 Photo survey Tacna - Arica. September 2015

(C) José Tomás Pérez

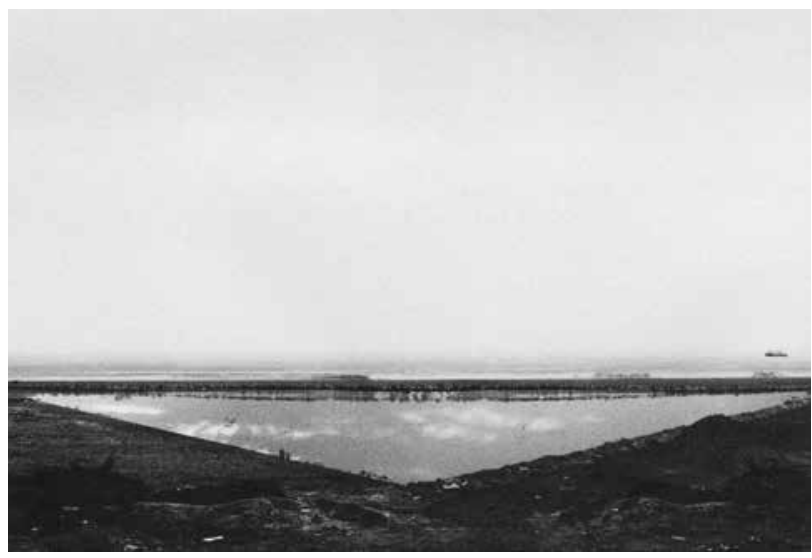

Imagen de proyecto / Project image
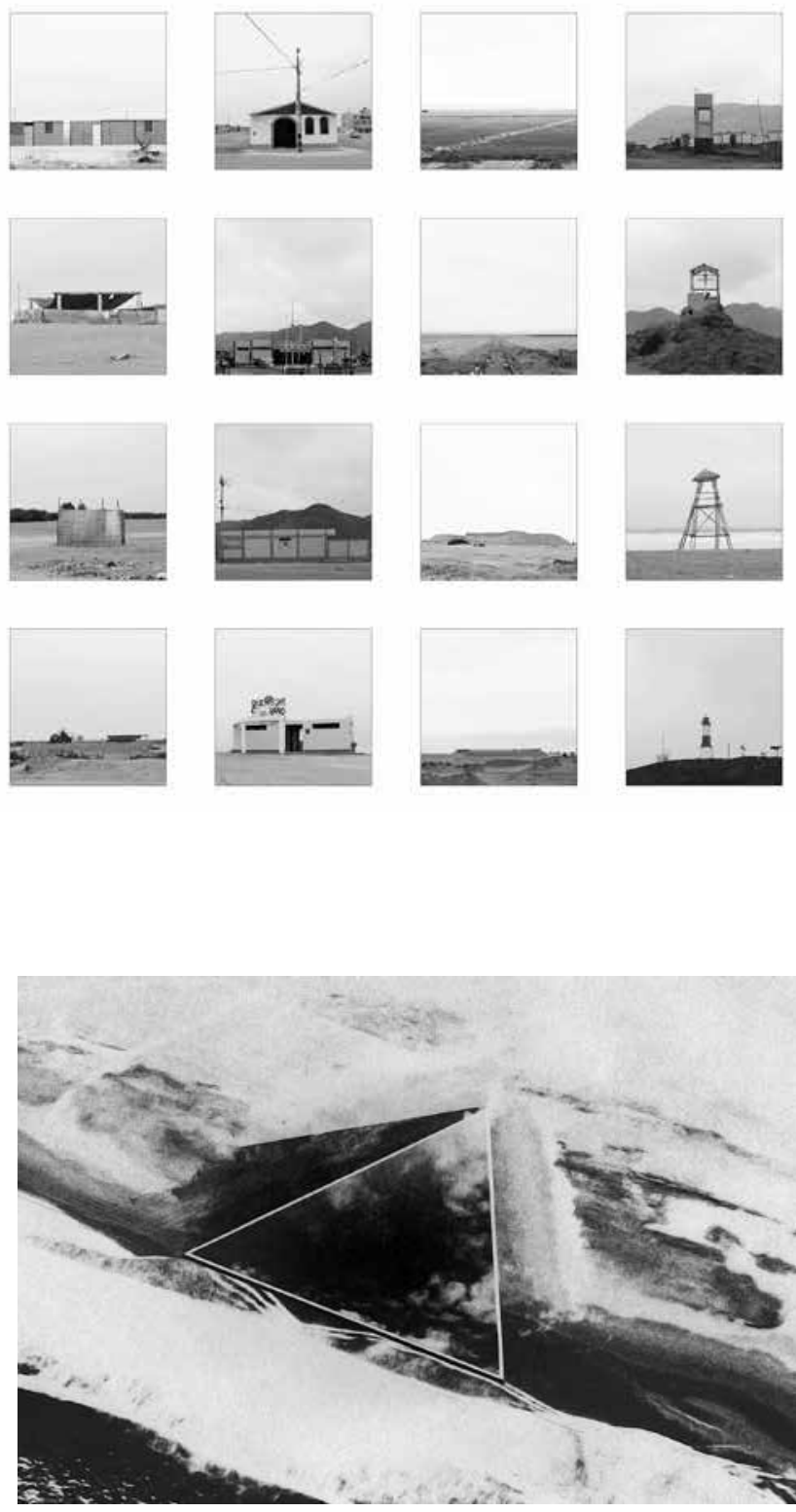

Imagen de proyecto / Project image

for the addition of a road section acting on a seaside plain of unprecedented spatial attributes for the regional context.

Today, understanding the historical panorama - beyond the last 87-years border condition - admits challenging the reductive construction based on the rivalries originated from the Pacific War. Thus - as a political decision - the project explores its ability to withstand the course of time and sees, in the border's future obsolescence, the maximum possible usage: a transition from the rubble of political conflict to a seaside place set in a binational coast.

The remains: an enclave-beach, in a symbolic central position, resisting the economic pressures proper of Tacna and Arica conurbation. ARQ 


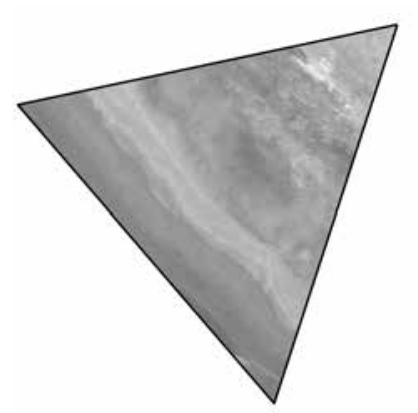

\section{BIBLIOGRAFÍA / BIBLIOGRAPHY}

BALT Z, Lewis. Park City. Nueva York: Aperture, I980. METAH AVEN. Uncorporate Identity. Zurich: Lars Müller, 2 oІо.

\section{JOSÉ TOMÁS PÉREZ}

Architect, Pontificia Universidad Católica de Chile, 2016. Undergraduate studies at the Oslo School of Architecture and Design (AHO), 2014.

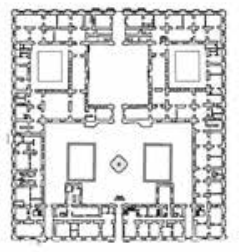

Arquitecto / Architect

José Tomás Pérez

Profesor guía / Tutor

Emilio De la Cerda

Ubicación / Location

Triángulo terrestre / Terrestrial triangle $\mathrm{CH} / \mathrm{PE}$ Cliente / Client

Proyecto de título / Architecture degree project Pontificia Universidad Católica de Chile Ingeniería / Engineering David Quezada

Sistema constructivo / Construction system Excavación y movimientos de tierra, arena seca y húmeda con refuerzos costeros de enrocado / Excavation and earthworks, dry and wet sand with rockfilled coastline reinforcements
Presupuesto / Budget

Us $\$ 110 / \mathrm{m}^{2}$

Superficie terreno / Site area $37.000 \mathrm{~m}^{2}$

Superficie de excavación / Excavation area $12.000 \mathrm{~m}^{2}$

Volumen a remover / Volume removed $208.900 \mathrm{~m}^{3}$

Año de proyecto / Project year $2015-2016$

Maquetas / Models

María Eugenia Schmidt, José Tomás Pérez Fotografías / Photographs José Tomás Pérez 